\title{
Ranking Green Producers of Livestock and Poultry Feed by Using a Hybrid Fuzzy MADM Method
}

\author{
Mehdi Alinaghian,", ${ }^{1, *}$ Mehrdad Karamipour ${ }^{2}$ \\ ${ }^{1}$ Department of Industrial and Systems Engineering, Isfahan University of Technology, Iran \\ ${ }^{2}$ Department of Industrial Engineering, Mazandaran University of Science and Technology, Iran
}

Copyright $\bigcirc 2015$ by authors, all rights reserved. Authors agree that this article remains permanently open access under the terms of the Creative Commons Attribution License 4.0 International License

\begin{abstract}
Supply chain management has increasingly attracted attention as a systematic approach to integrate the supply chain in order to planning and controlling the materials and information from suppliers to customers. Increasing importance of environmental issues led to the creation of a new concept called the Green supply chain management in the sphere of business that is actually a combination of environmental thought and as an aims to reduce the effects of supply chain manufacturing industries on the environment. Supplier selection is one of the most important issues in green supply chain management. In this paper, proper criteria are selected to evaluate the suppliers in livestock and poultry feed industry. Fuzzy Analytic Hierarchy Process (AHP) and Fuzzy Technique for Order Preference by Similarity to Ideal Solution (TOPSIS) are used as a hybrid multiple attribute decision making method to rank the suppliers. Finally proposed hybrid method and 16 criteria are applied to evaluate and rank three producers of livestock and poultry feed in Isfahan state of Iran.
\end{abstract}

Keywords Supplier Selection, GSCM, Fuzzy AHP, Fuzzy TOPSIS

\section{Introduction}

A supply chain management ( $\mathrm{SCM}$ ) is a system consists of three key parts, which are: the supply focuses on obtaining raw materials to manufacturing, the manufacturing focuses on converting obtained raw materials into finished products and the distribution focuses on reaching these finished products to customers through distributors, warehouses and retailers. Supply chain activities begin with customer orders and end with customer satisfactions. Selection of suppliers plays a critical role in an organization because it heavily contributes to the overall performance of a supply chain system. Assessing suppliers and selecting suitable ones among them a complex and critical decision making problem due to considering several criteria such as quality, cost, service, production lead time and environmental impact [1].

Environmental issues are no longer a concern only for environmental experts. Environmental awareness affects almost all parts of our society and it is a special concern for our industrial sectors [2,3]. Companies and their decision makers must consider environmental issues in all of their administrative activities [4], including the role of the supply chain [5] and the firms' selection of suppliers [6].

The supplier selection is a problem that companies face since the beginning of its activity. The choice of supplier/partner is one of the key factors for the operational success of many companies but also a time and resource-consuming complex process. Today, many companies need to constantly strengthen its competitiveness through reliable and efficient supply networks based on suppliers/partners relations in order to increase profit and promote customer value [7].

Supplier selection is a key operational task for developing sustainable supply chain partnerships. Environmental, social, and economic dimensions must all be considered in order to select a well-rounded sustainable supplier, one that can enhance supply chain performance. Part of the supplier selection process involves supplier evaluation together with selection, which is an important issue to supply chain and production and operation management literature [8].

Environmental sustainability has gained greater notoriety amongst organizations as industrial environmental impacts resoundingly occur at local, regional, and global levels. The industrial response has not just been reactive to these environmental concerns, but has included organizational search for competitive advantage $[9,10,11,12,13,14]$. These responses have also reverberated through organizational supply chains. One dimension of this important green supply chain response by organizations is the introduction of green supplier development (GSD) programs. Integrating environmental sustainability into supplier development has become a necessary measure for the long-term competitiveness and operations of focal companies and their 
supply chains $[15,16,17,18]$. The integration of environmental concerns within supply chain management has itself evolved into a separate and growing field. However, in order to improve relations with the environment, organizations need to implement strategies to reduce the environmental impacts of the entire supply chain during the production, consumption, customer service and disposal of products $[9,19]$.

Several environmental criteria may be emphasized when selecting the most environmentally friendly suppliers [20]. For example, several studies have suggested that the supplier selection can be based on the criteria related to environmental practices [21] or to hazardous material management [22].Yan [23] is used AHP and genetic algorithm to evaluate suppliers. Lee et al. [24] applied FAHP integrated with the Delphi method for green supplier evaluation. Chen et al. [25] apply fuzzy set theory accompanied with grey relational analysis for green supplier selection. Kuo and Lin [26] proposed a method which integrates ANP and DEA for green supplier evaluation.

In this paper, a set of proper supplier selection criteria in livestock and poultry feed industry are gathered and also a hybrid Fuzzy MADM method is used to rank suppliers that hold the vagueness in all steps of ranking procedure. Section 2 introduces the fuzzy AHP and Fuzzy TOPSIS. The new approach of supplier assessment in livestock and poultry feed industry is proposed in section 3. New approach application is presented in a case study in section 4 and finally section 5 contains the conclusion and some recommendations for future researches.

\section{Fuzzy AHP and Fuzzy TOPSIS}

Many process engineering problems involve the selection from a predefined set of alternatives, often using multiple, potentially conflicting criteria. Such cases require the systematic use of Multiple Attribute Decision Making (MADM) techniques to provide a rigorous and rational approach to problem-solving. In addition, industrial applications also tend to require the integration of viewpoints from multiple decision makers, such as personnel involved in different aspects of process engineering (e.g., design, operation maintenance). Thus, decision making tends to become a complex task that requires the development of appropriate process systems engineering (PSE) tools. In particular, MADM techniques have been shown to be effective for various problems, such as reactor selection [27], process diagnostics [28] and ranking of sustainable process options [29,30,31,32], among others Many MADM approaches entail the use of an aggregation function to derive a single composite score for each option being evaluated; various techniques make use of different aggregation philosophies, often with the integration of subjective inputs from decision makers.

\subsection{Fuzzy AHP}

The Analytic Hierarchy Process (AHP), originally developed by Saaty [33], is a theory of relative measurement that provides the analytical tool to model the complexity of the problem and the process of the subjective and personal judgment of individuals or a group in decision making. The underlying philosophy of AHP is to integrate subjectivity within a rigorous mathematical framework, rather than to try to eliminate it entirely from the decision-making process. In practice, the AHP framework provides a means of problem decomposition and structuring, so as to maximize coherence of the subjective judgments (which are usually elicited from domain experts). AHP has been widely used as an MADM tool or weight estimation technique in many areas of application [34,35], such as energy planning [36] and process safety assessment and design [37,38], among others.

Fuzzy set theory was first proposed as a means of representing ambiguity by Zadeh [39], and was subsequently extended for general decision-making applications by Bellman and Zadeh [40]. In particular, fuzzy set theory has been used to enhance various MADM techniques to incorporate uncertainties inherent in subjectivity. Many such extensions are described in Chen et al. [41]. In particular, fuzzy AHP (FAHP) was first proposed by Van Laarhoven and Pedrycz [42], who proposed to replace precise pair wise comparisons with Triangular Fuzzy Numbers (TFNs) and applied the fuzzy version of the Logarithmic Least Squares Method (LLSM).

In classical AHP directly the numerical values of linguistic variables are used for evaluation of criteria. If the environment where the decision making process takes place is fuzzy, then fuzzy numbers are used for evaluation concerning some deviations of decision makers. Nowadays, especially in complex economic conditions, many of the decisions are made in such an environment. Thus, fuzzy version of AHP or similar method should be used in spite of its complexity during the calculations [43].

Within the scope of this study, a fuzzy AHP model will be designed for supplier selection in Supply Chain Management. The solution procedure of the fuzzy AHP approach involves six essential steps as follows:

Step 1. Define the problem and state clearly the objectives and results

Step 2. Decompose the complex problem into a hierarchical sequential structure

Step 3. Employ pair-wise comparisons among decision elements and form comparison matrices with fuzzy numbers

Step 4. Use the extent analysis method to estimate the relative weights of the decision elements.

Chang [44] proposed a fuzzy AHP approach based on the extent analysis method, which is widely used in supplier selection problems [45,46]. This method uses linguistic variables to express the comparative judgments given by decision makers. Let $X=\left\{x_{1}, \ldots, x_{i}, \ldots, x_{n}\right\}$ represent an object set and $G=\left\{g_{1}, \ldots, g_{j}, \ldots, g_{m}\right\}$ a goal set. In 
the method proposed by Chang [44], each object, $x_{i}$, is taken and extent analysis is performed for each goal, $g_{j}$. Thus, $m$ extent analysis values for each object can be obtained, with the following signs:

$$
M_{g i}^{1}, \ldots, M_{g i}^{j}, \ldots, M_{g i}^{m} i=1,2, \ldots, n
$$

Where all the $M_{g i}^{j} ;(i=1,2, \ldots, m)$ are triangular fuzzy numbers.

The method follows the steps described next.

The value of fuzzy synthetic extent with respect to the $i^{\text {th }}$ object is defined as equation (1).

$$
S_{i}=\sum_{j=1}^{m} M_{g i}^{j} \times\left[\sum_{i=1}^{n} \sum_{j=1}^{m} M_{g i}^{j}\right]^{-1}
$$

To obtain $\sum_{j=1}^{m} M_{g i}^{j}$, perform the fuzzy addition operation of $\mathrm{m}$ extent analysis values for a particular matrix such as equation (2).

$$
\sum_{j=1}^{m} M_{g i}^{j}=\left(\sum_{j=1}^{m} l_{j}, \sum_{j=1}^{m} m_{j}, \sum_{j=1}^{m} u_{j}\right)
$$

And to obtain $\left[\sum_{i=1}^{n} \sum_{j=1}^{m} M_{g i}^{j}\right]^{-1}$, perform the fuzzy addition operation of $\mathrm{M}_{g i}^{j}$ value such as equation (3).

$$
\sum_{i=1}^{n} \sum_{j=1}^{m} M_{g i}^{j}=\left(\sum_{j=1}^{m} l_{j}, \sum_{j=1}^{m} m_{j}, \sum_{j=1}^{m} u_{j}\right)
$$

And then compute the inverse of the vector above equation (4).

$$
\left[\sum_{i=1}^{n} \sum_{j=1}^{m} M_{g i}^{j}\right]^{-1}=\left(\frac{1}{\sum_{i=1}^{n} u_{i}}, \frac{1}{\sum_{i=1}^{n} m_{i}}, \frac{1}{\sum_{i=1}^{n} l_{i}}\right)
$$

As $\tilde{M}_{1}=\left(l_{1}, \mathrm{~m}_{1}, \mathrm{u}_{1}\right)$ and $\tilde{M}_{2}=\left(l_{2}, \mathrm{~m}_{2}, \mathrm{u}_{2}\right)$ are two triangular fuzzy numbers, the degree of possibility of $\tilde{M}_{2}=\left(l_{2}, \mathrm{~m}_{2}, \mathrm{u}_{2}\right) \geq \tilde{M}_{1}=\left(l_{1}, \mathrm{~m}_{1}, \mathrm{u}_{1}\right)$ defined as equation (5).

$$
V\left(\tilde{M}_{2} \geq \tilde{M}_{1}\right)=\sup _{y \geq x}\left[\min \left(\mu_{\tilde{M}_{1}}(\mathrm{x}), \mu_{\tilde{M}_{2}}(\mathrm{y})\right)\right]
$$

And can be equivalently express as equation (6).

$$
V\left(\tilde{M}_{2} \geq \tilde{M}_{1}\right)=\left\{\begin{array}{l}
1 \\
0 \\
\frac{l_{1}-u_{2}}{\left(m_{2}-u_{2}\right)-\left(m_{1}-l_{1}\right)}
\end{array}\right.
$$

$$
\begin{gathered}
m_{2} \geq m_{1} \\
l_{1} \geq u_{2} \\
\text { otherwise }
\end{gathered}
$$

According to fuzzy sets theory [39], the representation of a fuzzy triangular number is given in Fig 1. In Fig 1, d is the ordinate of the highest intersection point of $\mathrm{D}$ between $\mu_{M_{1}}$ and $\mu_{M_{2}}$ to compare $M_{1}$ and $M_{2}$. We need both values of $V\left(\tilde{M}_{2} \geq \tilde{M}_{1}\right)$ and $V\left(\tilde{M}_{1} \geq \tilde{M}_{2}\right)$.

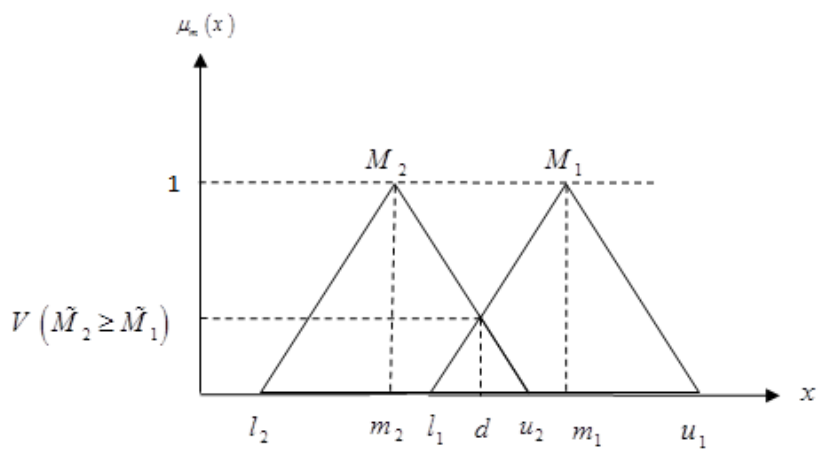

Figure 1. The intersection between $\tilde{M}_{2}$ and $\tilde{M}_{1}$ and their degree of possibility

The degree possibility for a convex fuzzy number to be greater than $\mathrm{k}$ convex fuzzy $M_{i} ;(i=1,2, \ldots, k)$ numbers can be defined by equation (7).

$$
\begin{aligned}
& V=\left(\mathrm{M} \geq \mathrm{M}_{1}, \mathrm{M}_{2}, \ldots, M_{k}\right) \\
& =\mathrm{V}\left[\left(M \geq M_{1}\right) \text { and }\left(M \geq M_{2}\right) \text { and } \ldots\left(M \geq M_{k}\right)\right] \\
& =\operatorname{minV}\left(M \geq M_{i}\right) ; i=1,2, \ldots, k
\end{aligned}
$$

Assume that $d\left(A_{i}\right)=\min V\left(S_{i} \geq S_{k}\right) \quad$ for $k=1,2, \ldots, n ; k \neq i$ Then thw weight vector is given by equation (8).

$$
W^{\prime}=\left(d^{\prime}\left(A_{1}\right), d^{\prime}\left(A_{2}\right), \ldots, d^{\prime}\left(A_{n}\right)\right)^{T}
$$

Where $A_{i} ;(i=1,2, \ldots, \mathrm{n})$ are n elements.

Via normalization, the normalized weight vectors are as equation (9).

$$
W=\left(d\left(A_{1}\right), d\left(A_{2}\right), \ldots, d\left(A_{n}\right)\right)^{T}
$$

Where $\mathrm{W}$ is a crisp number.

Step 5. Check the consistency of matrices to ensure that the judgments of decision makers are consistent.

Step 6. Aggregate the relative weights of decision elements to obtain an overall rating for the alternatives.

\subsection{Fuzzy TOPSIS}

Hwang and Yoon [47] first developed TOPSIS method. The main idea of TOPSIS is that the best alternatives should 
have farthest distance from the negative ideal solution (NIS) and the shortest distance from the positive ideal solution (PIS). Because a real world environment is full of ambiguities, several researches have investigated MCDM problems with fuzzy theory [48]. In this case, the Fuzzy TOPSIS method, which is one of the fuzzy MADM methods, could be applied as an efficient tool for the supplier selection problem in supply chain system. Chen et al [49] used fuzzy TOPSIS method for supplier evaluation and selection in supply chain management. Boran et al [50] proposed TOPSIS method combined with intuitionistic fuzzy set to select appropriate supplier in group decision making environment. Since criteria affecting supplier selection problem are multidimensional, they should be evaluated using the TOPSIS in fuzzy environment with regards to more than one criterion as hierarchical to get more precise, consistent, and reliable results. In general, fuzzy TOPSIS can solve MADM problems when hierarchy is a three-layer model. This three-layer model includes goal, criteria (attributes), and alternatives. Kahraman [51] extended the fuzzy TOPSIS method to a hierarchical one named hierarchical fuzzy TOPSIS method that has ability to handle the hierarchy among the attributes and alternatives. This method inherits the hierarchy mechanism of AHP method [52]. This method provides greater superiority to classical fuzzy TOPSIS methods [53]. Moreover, hierarchical fuzzy TOPSIS does not have disadvantages of the pairwise comparisons among criteria, sub criteria and alternatives. Therefore, this research proposes the fuzzy hierarchical TOPSIS for supplier selection and evaluation in detergent production industry, which overcome disadvantages of Chen's fuzzy TOPSIS [54] for normalization and determining the fuzzy positive and negative ideal solutions.

The solution procedure of the fuzzy TOPSIS approach involves seven essential steps as follows:

Step 1.The decision matrix is formed as equation (10).

$$
D=\left(\begin{array}{ccccc}
\tilde{x}_{11} & \cdots & \tilde{x}_{1 j} & \cdots & \tilde{x}_{1 n} \\
\vdots & \ddots & \vdots & \ddots & \vdots \\
\tilde{x}_{i 1} & \cdots & \tilde{x}_{i j} & \cdots & \tilde{x}_{i n} \\
\vdots & \ddots & \vdots & \ddots & \vdots \\
\tilde{x}_{m 1} & \cdots & \tilde{x}_{m j} & \cdots & \tilde{x}_{m n}
\end{array}\right)
$$

$D$ is a $m * n$ matrix. $m$ and $n$ represent the number of alternative and attributes, respectively. $\tilde{x}_{i j}$ is a triangular fuzzy number which is shown as $\tilde{x}_{i j}=\left(l_{i j}, m_{i j}, u_{i j}\right)$. Fuzzy weights are calculated as $\tilde{w}_{j}=\left(\alpha_{j}, \beta_{j}, \chi_{j}\right)$.
Step 2. After obtaining decision matrix, it should be normalized to make its elements unit free. Normalize the fuzzy decision matrix using linear scale transformation. The normalized fuzzy decision matrix $\tilde{R}=\left[\tilde{r}_{i j}\right]_{m * n}$ is given as equation (11).

$\tilde{r}_{i j}=\left(\frac{l_{i j}}{u_{j}^{+}}, \frac{m_{i j}}{u_{j}^{+}}, \frac{u_{i j}}{u_{j}^{+}}\right)$and $u_{j}^{+}=\max _{i} u_{i j}$ (benefit criteria)

$\tilde{r}_{i j}=\left(\frac{l_{j}^{-}}{u_{i j}}, \frac{l_{j}^{-}}{m_{i j}}, \frac{l_{j}^{-}}{l_{i j}}\right)$ and $l_{j}^{-}=\max _{i} l_{i j} \quad$ (cost criteria)

Step 3. Compute the weighted normalized decision matrix $(\tilde{V})$, by multiplying the weightes of the evaluation criteria $\left(\tilde{w}_{j}\right)$,by to elements $r_{i j}$ of the normalized fuzzy decision matrix

$$
\tilde{V}=\left[\tilde{v}_{i j}\right]_{m * n} \text {. Where } \tilde{v}_{i j} \text { is given by } \tilde{v}_{i j}=\tilde{r}_{i j} * \tilde{w}_{i j} .
$$

Step 4.Define the fuzzy positive ideal solution $\left(A^{+}\right)$and the fuzzy negative ideal solution $\left(A^{-}\right)$, as equation (12).

$$
A^{+}=\left\{\tilde{v}_{1}^{+}, \ldots \tilde{v}_{j}^{+}, \ldots, \tilde{v}_{m}^{+}\right\} \quad A^{-}=\left\{\tilde{v}_{1}^{-}, \ldots \tilde{v}_{j}^{-}, \ldots, \tilde{v}_{m}^{-}\right\}
$$

Step 5.Compute the distances $d_{i}^{+}$and $d_{i}^{-}$of each alternative from respectively $\tilde{v}_{j}^{+}$and $\tilde{v}_{j}^{-}$according to equation (13).

$$
d_{i}^{+}=\sum_{j=1}^{n} d v\left(\tilde{v}_{i j}, \tilde{v}_{j}^{+}\right) d_{i}^{-}=\sum_{j=1}^{n} d v\left(\tilde{v}_{i j}, \tilde{v}_{j}^{-}\right)
$$

Where $d(.,$.$) represent the distance between two fuzzy$ numbers according to the vertex method. For triangular fuzzy numbers, this is expressed as equation (14).

$$
d(\tilde{x}, \tilde{z})=\sqrt{\frac{1}{3}\left[\left(l_{x}-l_{z}\right)^{2}+\left(m_{x}-m_{z}\right)^{2}+\left(u_{x}-u_{z}\right)^{2}\right]}
$$

Step 6. Compute the closeness coefficient, $\boldsymbol{C}_{\boldsymbol{i}}$ according to equation (15).

$$
C_{i}=\frac{d_{i}^{-}}{d_{i}^{-}+d_{i}^{+}}
$$

Step 7. Ranking the alternatives

According to descending order of $C_{i}$ all alternatives are ranked. 


\section{Methodology}

Supplier selection based on environmental criteria has attracted the attention of many investigators. The summary of the most cited articles have been selected and listed in Table 1 that some of these criteria such as green product, cost, ISO 14000 and etc. are common thus they are used in this paper to form the hierarchical structure model.

Table 1. Ten top cited article in green supplier selection.

\begin{tabular}{|c|c|c|}
\hline Author(s) & Title of article & Supplier selection criteria \\
\hline Min and Galle [55] & Green purchasing practices of US firms & $\begin{array}{l}\text { (1) Environmental liability and penalty } \\
\text { (2) A supplier's environmental commitment } \\
\text { (3) Environmental cost }\end{array}$ \\
\hline Lee et al. [24] & $\begin{array}{l}\text { A green supplier selection model for high-tech } \\
\text { industry. }\end{array}$ & $\begin{array}{l}\text { (1) Quality } \\
\text { (2) Technology capability } \\
\text { (3) Pollution control } \\
\text { (4) Environmental management } \\
\text { (5) Green product } \\
\text { (6) Green competencies }\end{array}$ \\
\hline Jabbour and Jabbour [19] & $\begin{array}{l}\text { Are supplier selection criteria going green? } \\
\text { Case studies of companies in Brazil. }\end{array}$ & $\begin{array}{l}\text { (1) Cost } \\
\text { (2) Quality } \\
\text { (3) Innovation } \\
\text { (4) Delivery } \\
\text { (5) Restrictions on the use of chemicals } \\
\text { (6) ISO } 14001\end{array}$ \\
\hline Kuo et al. [56] & $\begin{array}{c}\text { Integration of artificial neural network } \\
\text { and MADA methods for green supplier } \\
\text { selection. }\end{array}$ & $\begin{array}{l}\text { (1) Quality } \\
\text { (2) Service } \\
\text { (3) Corporate social responsibility } \\
\text { (4) Delivery } \\
\text { (5) Cost } \\
\text { (6) Environment }\end{array}$ \\
\hline Wolf and Seuring [57] & $\begin{array}{c}\text { Environmental impacts as buying criteria for } \\
\text { third } \\
\text { party logistical services. }\end{array}$ & $\begin{array}{l}\text { (1) Cost } \\
\text { (2) Lead time } \\
\text { (3) Reliability } \\
\text { (4) Variety } \\
\text { (5) Quality } \\
\text { (6) Environment }\end{array}$ \\
\hline Yeh and Chuang [58] & $\begin{array}{l}\text { Using multi-objective genetic algorithm for } \\
\text { partner } \\
\text { selection in green supply chain problems. }\end{array}$ & $\begin{array}{l}\text { (1) Capability } \\
\text { (2) Productivity } \\
\text { (3) Cost } \\
\text { (4) Quality } \\
\text { (5) ISO } 14000 \\
\end{array}$ \\
\hline $\begin{array}{c}\text { Buyukozkan and Cifci } \\
\text { [59] }\end{array}$ & $\begin{array}{l}\text { A novel hybrid MCDM approach based on } \\
\text { fuzzy } \\
\text { DEMATEL, fuzzy ANP and fuzzy TOPSIS to } \\
\text { evaluate green suppliers. }\end{array}$ & $\begin{array}{l}\text { (1) Organization } \\
\text { (2) Financial performance } \\
\text { (3) Quality } \\
\text { (4) Technology } \\
\text { (5) Corporative social and environmental } \\
\text { Responsibility }\end{array}$ \\
\hline Shaw et al. [60] & $\begin{array}{c}\text { Supplier selection using fuzzy AHP and fuzzy } \\
\text { multi-objective linear programming for } \\
\text { developing } \\
\text { low carbon supply chain. }\end{array}$ & $\begin{array}{l}\text { (1) Cost } \\
\text { (2) Quality } \\
\text { (3) Delivery } \\
\text { (4) Emissions of greenhouse gases } \\
\end{array}$ \\
\hline Tseng and Chiu [61] & $\begin{array}{c}\text { Evaluating firm's green supply chain } \\
\text { management } \\
\text { in linguistic preferences. }\end{array}$ & $\begin{array}{l}\text { (1) Delivery } \\
\text { (2) Financial performance } \\
\text { (3) Relationship } \\
\text { (4) Quality } \\
\text { (5) Price } \\
\text { (6) Green design } \\
\text { (7) ISO } 14000 \\
\text { (8) Green purchasing } \\
\text { (9) Cleaner production }\end{array}$ \\
\hline $\begin{array}{c}\text { Jinus Roshandel et al. } \\
\text { [62] }\end{array}$ & $\begin{array}{l}\text { Selecting green suppliers based on GSCM } \\
\text { practices: Using fuzzy TOPSIS applied to a } \\
\text { Brazilian electronics company. }\end{array}$ & $\begin{array}{l}\text { (1) Quality } \\
\text { (2) Delivery } \\
\text { (3)Cost/Price } \\
\text { (4) Technology } \\
\text { (5) Flexibility } \\
\text { (6) Responsiveness \& services }\end{array}$ \\
\hline
\end{tabular}


The proposed approach involves six essential steps as follows:

Step 1: propose proper set of criteria

First a long list of criteria that are used for green supplier ranking in literature is formed and then the modification is done based on experts' opinions with regard to the especial specifications of Livestock and Poultry Feed industry. The 8 experts' opinions provide a short list of criteria that contains 5 criteria (Green Concept, Finance, Services and Marketing, IT and quality) and 16 sub-criteria (Green Education, Green Packaging, ISO 14000 \& OHSAS 18001, Green Design \& Manufacturing, The final Price, Financial Status, Logistics Costs, After sales Service, Accountability in Emergencies, Market Share, R \& D, Internet services, Advertising Information, The Quality Management System and Certificates of Quality) for Green Producers of Livestock and Poultry Feed Ranking problem.

Sustainable packaging is a relatively new addition to the environmental considerations for packaging. Environmental education or green education refers to organized efforts to teach how natural environments function, and particularly, how human beings can manage behavior and ecosystems to live sustainably. It is a multi-disciplinary field integrating disciplines such as biology, chemistry, physics, ecology, earth science, atmospheric science, mathematics, and geography. The term often implies education within the school system, from primary to post-secondary. However, it sometimes includes all efforts to educate the public and other audiences, including print materials, websites, media campaigns, etc. Sustainable design (also called environmental design, environmentally sustainable design, environmentally conscious design, etc.) is the philosophy of designing physical objects, the built environment, and services to comply with the principles of social, economic, and ecological sustainability and Green Manufacturing refers to reducing resource use, waste and emissions.

ISO 14000 is a series of environmental management standards developed and published by the International Organization for Standardization (ISO) for organizations. The ISO 14000 standards provide a guideline or framework for organizations that need to systematize and improve their environmental management efforts. OHSAS 18001, Occupational Health and Safety Management Systems-Requirements (officially BS OHSAS 18001) is an internationally applied British Standard for occupational health and safety management systems. It exists to help all kinds of organizations put in place demonstrably sound occupational health and safety performance. It is a widely recognized and popular occupational health and safety management system

Step 2: propose hierarchical structure of problem

Figure 2 represents the hierarchical structure of Livestock and Poultry Feed Ranking problem based on 8 experts' opinions.

Step 3: propose fuzzy pairwise comparison matrices Step 4: compute fuzzy weights of each element in AHP

Step 5: propose fuzzy decision matrices

Step 6: use fuzzy TOPSIS to ranks alternatives 


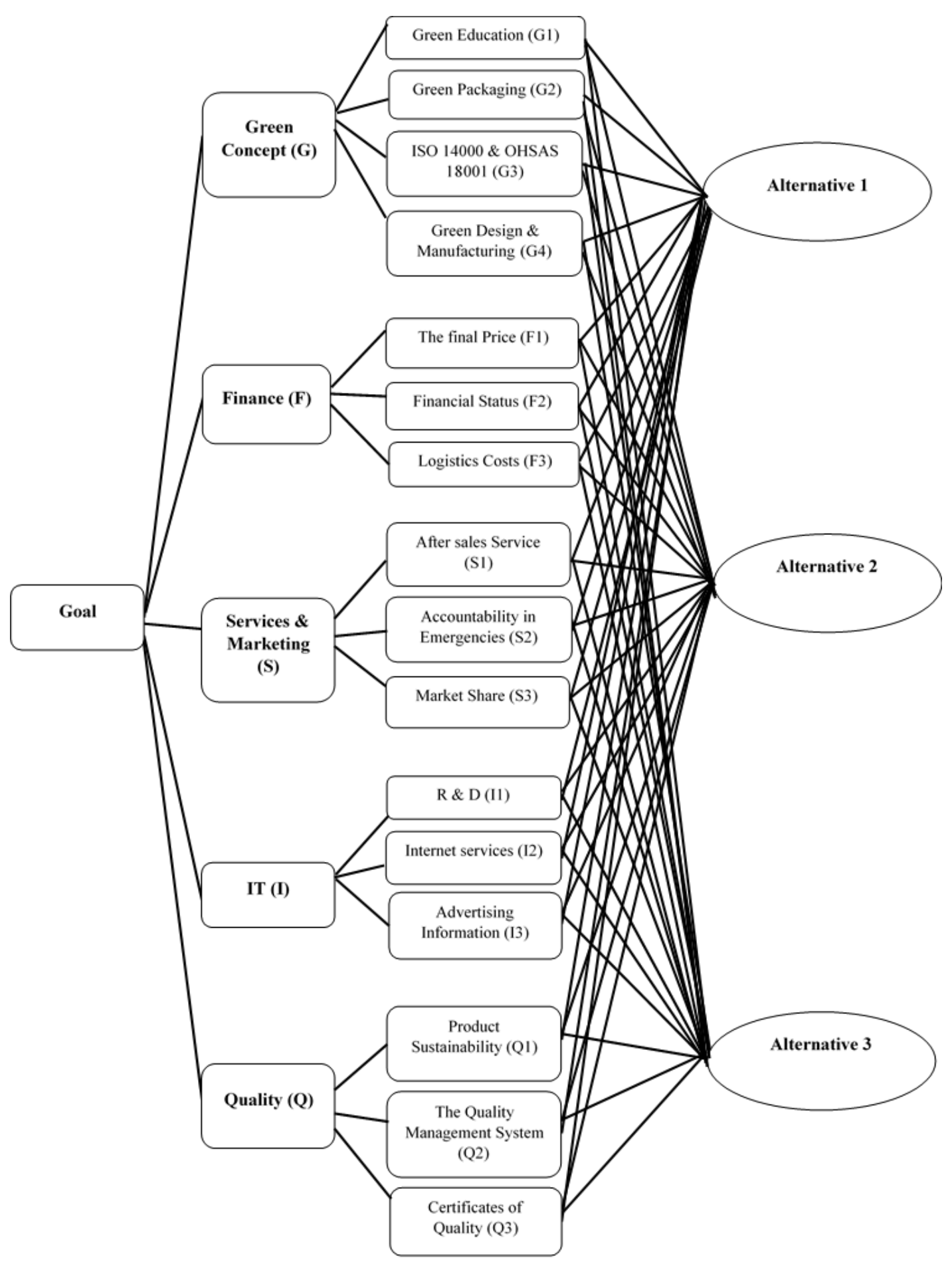

Figure 2. Hierarchical structure of problem

\section{Case Study}

The proper feed for livestock and poultry has high importance. Hence, in Isfahan province, livestock and poultry breeders are looking for the best supplier in this industry. Three suppliers of livestock and poultry feed that called Khorak sazan espadan, Khorak dame koohpayeh and Sepahandaneh parsian are mentioned. These companies are introduced in follow.

Khorak sazan espadan Co: This Company is started in
2008 by getting permission from the Bureau of mines and industries of Isfahan Province began to build and launch in 2010 and has begun to produce. The company in the field of livestock and poultry and aquaculture feed production with advanced devices, high technology and automatic systems. The products of company are distributed in Iran.

Khorak dame koohpayeh Co: Livestock and poultry production complex Foothills project started in 2005 and its first phase was put into operation in 2007. The complex specialists and experts, and enjoying the best food formulas 
prepared with the highest quality materials and institutions as well as having advanced machines to produce top quality feed for livestock and poultry in that order. The complex also has a biological and chemical laboratories and a research farm with a capacity of 40 thousand pieces of chicken meat all raw materials and products in accordance with the latest standards and assessments will measure.

Sepahandaneh parsian Co: The Sepahan Grain Corp in 2005 , backed by ten years in the industry with the Animal Plant science in nutrition, health, GSI started its activities. These companies on their mission and sincere service, innovation-oriented science, optimization of the production cycle and finally, the product is affordable and well built. In this context, strongest team of expert collaborators in the scientific and R \& D Specialist in Animal Plant for the better of the following services have attempted to provide the following services: Innovation in the production of various concentrates, feed supplements and Plant based on latest technology to achieve the highest efficiency in the animal husbandry industry production and Startup Manager, Quality Engineering (QE) system based on TQM and so on.

To determine importance of criteria and sub-criteria, a questionnaire about status of three supplier in Esfahan is designed and distributed among 8 experts. After collecting experts's opinions, FAHP and FTOPSIS model are used to evaluate and select the best supplier. Fig 2 shows the proposed hierarchical structure. In this figure, the main objective, criteria, sub-criteria, and alternatives are shown in the first, second, third, and forth levels, respectively.

To determine degree of importance for each major criterion than the objective, and also sub-criterion than the main criterion, Table $2 \mathrm{a}$ and $2 \mathrm{~b}$ are used.

Table 2a. Linguistic scales for importance degree of each criterion and subcriterion

\begin{tabular}{|c|c|}
\hline Linguistic variables & Triangular fuzzy number \\
\hline Full preferrence & $(7,9,11)$ \\
\hline Very strong preference & $(5,7,9)$ \\
\hline Strong preference & $(3,5,7)$ \\
\hline Low preference & $(1,3,5)$ \\
\hline Equal preference & $(1,1,1)$ \\
\hline
\end{tabular}

Table 2b. Linguistic scales for importance degree of each criterion and subcriterion.

\begin{tabular}{|c|c|}
\hline Linguistic variables & Triangular fuzzy number \\
\hline Yes & $(1,1,1)$ \\
\hline No & $(0,0,0)$ \\
\hline
\end{tabular}

At first, average of all expert's opinions is calculated and the pairwise comparison matrices are formed which shows in Tables 3-8.

Table 3. The pairwise comparison matrix.

\begin{tabular}{|c|c|c|c|c|c|}
\hline Goal & Green & Finance & Services \& Marketing & IT & Quality \\
\hline Green & $(1,1,1)$ & $(1,3,5)$ & $(5,7,9)$ & $(7,9,11)$ & $(1,3,5)$ \\
\hline Finance & $(1 / 5,1 / 3,1)$ & $(1,1,1)$ & $(3,5,7)$ & $(5,7,9)$ & $(1,1,1)$ \\
\hline $\begin{array}{c}\text { Services \& } \\
\text { Marketing }\end{array}$ & $(1 / 9,1 / 7,1 / 5)$ & $(1 / 7,1 / 5,1 / 3)$ & $(1,1,1)$ & $(1,3,5)$ & $(1 / 5,1 / 3,1)$ \\
\hline IT & $(1 / 11,1 / 9,1 / 7)$ & $(1 / 9,1 / 7,1 / 5)$ & $(1 / 5,1 / 3,1)$ & $(1,1,1)$ & $(1 / 7,1 / 5,1 / 3)$ \\
\hline Quality & $(1 / 5,1 / 3,1)$ & $(1,1,1)$ & $(1,3,5)$ & $(3,5,7)$ & $(1,1,1)$ \\
\hline
\end{tabular}

The above table says the green criteria are more important than the other criteria.

Table 4. The pairwise comparison matrix.

\begin{tabular}{|c|c|c|c|c|}
\hline Green & Green Education & Green Packaging & $\begin{array}{c}\text { ISO 14000 ISO 14000 } \\
\text { \& OHSAS 1001 }\end{array}$ & $\begin{array}{c}\text { Green Design \& } \\
\text { Manufacturing }\end{array}$ \\
\hline Green Education & $(1,1,1)$ & $(1 / 5,1 / 3,1)$ & $(1 / 7,1 / 5,1 / 3)$ & $(1 / 7,1 / 5,1 / 3)$ \\
\hline $\begin{array}{c}\text { Green Packaging } \\
\text { ISO 14000 \& OHSAS } \\
1001\end{array}$ & $(1,3,5)$ & $(1,1,1)$ & $(1,1,1)$ & $(1 / 5,1 / 3,1)$ \\
\hline $\begin{array}{c}\text { Green Design \& } \\
\text { Manufacturing }\end{array}$ & $(1,3,5)$ & $(1,3,5)$ & $(1,1,1)$ & $(1,1,1)$ \\
\hline
\end{tabular}

The above table shows ISO 14000 \& OHSAS 1001 are more important than the other criteria.

Table 5. The pairwise comparison matrix.

\begin{tabular}{|c|c|c|c|}
\hline Finance & The final Price & Financial Status & Logistics Costs \\
\hline The final Price & $(1,1,1)$ & $(3,5,7)$ & $(1,3,5)$ \\
\hline Financial Status & $(1 / 7,1 / 5,1 / 3)$ & $(1,1,1)$ & $(1 / 5,1 / 3,1)$ \\
\hline Logistics Costs & $(1 / 5,1 / 3,1)$ & $(1,3,5)$ & $(1,1,1)$ \\
\hline
\end{tabular}

The above table says the final price is more important than the other criteria. 
Table 6. The pairwise comparison matrix.

\begin{tabular}{|c|c|c|c|}
\hline Services \& Marketing & After sales Service & $\begin{array}{c}\text { Accountability in } \\
\text { Emergencies }\end{array}$ & Market Share \\
\hline After sales Service & $(1,1,1)$ & $(1 / 5,1 / 3,1)$ & $(1 / 7,1 / 5,1 / 3)$ \\
\hline Accountability in Emergencies & $(1,3,5)$ & $(1,1,1)$ & $(1 / 7,1 / 5,1 / 3)$ \\
\hline Market Share & $(3,5,7)$ & $(3,5,7)$ & $(1,1,1)$ \\
\hline
\end{tabular}

The above table shows market share is more important than the other criteria.

Table 7. The pairwise comparison matrix.

\begin{tabular}{|c|c|c|c|}
\hline IT & R \& D & Internet services & advertising Information \\
\hline R \& D & $(1,1,1)$ & $(3,5,7)$ & $(1,3,5)$ \\
\hline Internet services & $(1 / 7,1 / 5,1 / 3)$ & $(1,1,1)$ & $(1 / 5,1 / 3,1)$ \\
\hline Advertising Information & $(1 / 5,1 / 3,1)$ & $(1,3,5)$ & $(1,1,1)$ \\
\hline
\end{tabular}

The above table says R \& D is more important than the other criteria.

Table 8. The pairwise comparison matrix.

\begin{tabular}{|c|c|c|c|}
\hline Quality & Product Sustainability & $\begin{array}{c}\text { The Quality Management } \\
\text { System }\end{array}$ & Certificates of Quality \\
\hline Product Sustainability & $(1,1,1)$ & $(1 / 7,1 / 5,1 / 3)$ & $(1 / 9,1 / 7,1 / 5)$ \\
\hline $\begin{array}{c}\text { The Quality Management } \\
\text { System }\end{array}$ & $(3,5,7)$ & $(1,1,1)$ & $(1 / 5,1 / 3,1)$ \\
\hline Certificates of Quality & $(5,7,9)$ & $(1,3,5)$ & $(1,1,1)$ \\
\hline
\end{tabular}

The above table shows certificates of quality are more important than the other criteria.

There are 16 paired comparison matrices in the final level of the proposed AHP structure, as a sample, the paired comparison matrix of alternatives than one of the sub criterion has come in Table 9.

Table 9. Final weights of each sub criterion

\begin{tabular}{|c|c|c|c|}
\hline Green Education & Alternative 1 & Alternative 2 & Alternative 3 \\
\hline Alternative 1 & $(1,1,1)$ & $(1,3,5)$ & $(1 / 7,1 / 3,1)$ \\
\hline Alternative 2 & $(1 / 5,1 / 3,1)$ & $(1,1,1)$ \\
\hline Alternative 3 & $(1,3,5)$ & $(3,5,7)$ & $(1,1,1)$ \\
\hline
\end{tabular}

The final weight of each criterion is calculated by fuzzy multiplying weight of each sub-criterion than the criterion to the weight of criterion than the objective. Results are indicated in Table 10.

Table 10. Final weights of each sub criterion

\begin{tabular}{|c|c|c|c|}
\hline $\begin{array}{c}\text { Green Education } \\
(0.008,0.0287,0.1653)\end{array}$ & $\begin{array}{c}\text { Green Packaging } \\
(0.014,0.0779,0.4872)\end{array}$ & $\begin{array}{c}\text { ISO 14000, OHSAS } \\
(0.036,0.164,0.8526)\end{array}$ & $\begin{array}{c}\text { Green Design } \\
(0.024,0.1476,0.7308)\end{array}$ \\
\hline $\begin{array}{c}\text { The final Price } \\
(0.026,0.1638,0.8268)\end{array}$ & $\begin{array}{c}\text { Financial Status } \\
(0.0065,0.026,0.1484)\end{array}$ & $\begin{array}{c}\text { Logistics Costs } \\
(0.0117,0.078,0.4452)\end{array}$ & $\begin{array}{c}\text { After sales Service } \\
(0.0015,0.0076,0.0483)\end{array}$ \\
\hline $\begin{array}{c}\text { Accountability in } \\
\text { Emergencies } \\
(0.0024,0.218,0.1323)\end{array}$ & $\begin{array}{c}\text { Market Share } \\
(0.0084,0.0554,0.315)\end{array}$ & $\begin{array}{c}\text { R \& D } \\
(0.004,0.0189,0.1092)\end{array}$ & $\begin{array}{c}\text { Internet services } \\
(0.001,0.003,0.0196)\end{array}$ \\
\hline $\begin{array}{c}\text { Advertising Information } \\
(0.0018,0.009,0.0558)\end{array}$ & $\begin{array}{c}\text { Product Sustainability } \\
(0.004,0.0133,0.0504)\end{array}$ & $\begin{array}{c}\text { The Quality Management } \\
\text { System }\end{array}$ & $\begin{array}{c}\text { Certificates of Quality } \\
(0.0224,0.1045,0.504)\end{array}$ \\
\hline
\end{tabular}

The above table shows the green criteria are more important than the other criteria because they have more weights.

After calculating the final weight of sub-criteria, according to expert decision matrix is formed that show in Table 11. 
Table 11. Decision matrix.

\begin{tabular}{|c|c|c|c|}
\hline Sub-criterion & Supplier 1 & Supplier 2 & Supplier 3 \\
\hline G1 & $(5,7,9)$ & $(5,7,9)$ & $(7,9,11)$ \\
\hline G2 & $(3,5,7)$ & $(3,5,7)$ & $(5,7,9)$ \\
\hline G3 & $(0,0,0)$ & $(0,0,0)$ & $(1,1,1)$ \\
\hline G4 & $(0,0,0)$ & $(0,0,0)$ & $(3,5,7)$ \\
\hline F1 & $(5,7,9)$ & $(5,7,9)$ & $(3,5,7)$ \\
\hline F2 & $(5,7,9)$ & $(3,5,7)$ & $(3,5,7)$ \\
\hline F3 & $(5,7,9)$ & $(5,7,9)$ & $(5,7,9)$ \\
\hline S1 & $(5,7,9)$ & $(3,5,7)$ & $(7,9,11)$ \\
\hline S2 & $(7,9,11)$ & $(5,7,9)$ & $(5,7,9)$ \\
\hline S3 & $(7,9,11)$ & $(5,7,9)$ & $(1,1,1)$ \\
\hline I1 & $(1,1,1)$ & $(0,0,0)$ & $(7,9,11)$ \\
\hline I2 & $(5,7,9)$ & $(1,3,5)$ & $(7,9,11)$ \\
\hline I3 & $(7,9,11)$ & $(5,7,9)$ & $(5,7,9)$ \\
\hline Q1 & $(5,7,9)$ & $(3,5,7)$ & $(5,7,9)$ \\
\hline Q2 & $(3,5,7)$ & $(3,5,7)$ & $(7,9,11)$ \\
\hline Q3 & $(5,7,9)$ & $(5,7,9)$ & \\
\hline
\end{tabular}

Table 12 and 13 shows normalized decision matrix and normalized weighted decision matrix respectively.

Table 12. Normalized decision matrix

\begin{tabular}{|c|c|c|c|}
\hline Sub-criterion & Supplier 1 & Supplier 2 & Supplier 3 \\
\hline G1 & $(5 / 11,7 / 11,9 / 11)$ & $(5 / 11,7 / 11,9 / 11)$ & $(7 / 11,9 / 11,1)$ \\
\hline G2 & $(3 / 9,5 / 9,7 / 9)$ & $(3 / 9,5 / 9,7 / 9)$ & $(5 / 9,7 / 9,1)$ \\
\hline G3 & $(0,0,0)$ & $(0,0,0)$ & $(1,1,1)$ \\
\hline G4 & $(0,0,0)$ & $(0,0,0)$ & $(3 / 7,3 / 1)$ \\
\hline F1 & $(3 / 9,3 / 7,3 / 5)$ & $(3 / 9,3 / 7,3 / 5)$ \\
\hline F2 & $(5 / 9,7 / 9,1)$ & $(3 / 9,5 / 9,7 / 9)$ & $(3 / 9,5 / 9,7 / 9)$ \\
\hline F3 & $(3 / 9,3 / 7,3 / 5)$ & $(3 / 9,3 / 7,3 / 5)$ & $(3 / 7,3 / 5,3 / 3)$ \\
\hline S1 & $(5 / 9,7 / 9,1)$ & $(3 / 9,5 / 9,7 / 9)$ & $(5 / 9,7 / 9,1)$ \\
\hline S2 & $(7 / 11,9 / 11,1)$ & $(5 / 11,7 / 11,9 / 11)$ & $(5 / 11,7 / 11,9 / 11)$ \\
\hline S3 & $(7 / 11,9 / 11,1)$ & $(5 / 11,7 / 11,9 / 11)$ & $(1,1,1)$ \\
\hline I1 & $(1,1,1)$ & $(0,0,0)$ & $(7 / 11,9 / 11,1)$ \\
\hline I2 & $(5 / 11,7 / 11,9 / 11)$ & $(1 / 11,3 / 11,5 / 11)$ & $(7 / 11,9 / 11,1)$ \\
\hline I3 & $(7 / 11,9 / 11,1)$ & $(5 / 11,7 / 11,9 / 11)$ & $(5 / 9,7 / 9,1)$ \\
\hline Q1 & $(5 / 9,7 / 9,1)$ & $(3 / 9,5 / 9,7 / 9)$ & $(5 / 9,7 / 9,1)$ \\
\hline Q2 & $(3 / 9,5 / 9,7 / 9)$ & $(3 / 9,5 / 9,7 / 9)$ & $(7 / 11,9 / 11,1)$ \\
\hline Q3 & $(5 / 11,7 / 11,9 / 11)$ & $(5 / 11,7 / 11,9 / 11)$ & \\
\hline
\end{tabular}

Table 13. Normalized weighted decision matrix.

\begin{tabular}{|c|c|c|c|}
\hline Sub-criterion & Supplier 1 & Supplier 2 & Supplier 3 \\
\hline G1 & $(0.004,0.018, .135)$ & $(0.004,0.018, .135)$ & $(0.005,0.023,0.17)$ \\
\hline G2 & $(0.005,0.043,0.379)$ & $(0.005,0.043,0.379)$ & $(0.008,0.06,0.48)$ \\
\hline G3 & $(0,0,0)$ & $(0,0,0)$ & $(0.024,0.144,0.853)$ \\
\hline G4 & $(0,0,0)$ & $(0,0,0)$ & $(0.011,0.098,0.827)$ \\
\hline F1 & $(0.009,0.071,0.496)$ & $(0.009,0.071,0.496)$ & $(0.002,0.014,0.115)$ \\
\hline F2 & $(0.004,0.02,0.148)$ & $(0.002,0.014,0.115)$ & $(0.005,0.047,0.445)$ \\
\hline F3 & $(0.004,0.033,0.267)$ & $(0.004,0.033,0.267)$ & $(0.002,0.018,0.132)$ \\
\hline S1 & $(0.001,0.006,0.048)$ & $(0.001,0.004,0.038)$ & $(0.004,0.035,0.258)$ \\
\hline S2 & $(0.002,0.018,0.132)$ & $(0.001,0.013,0.108)$ & $(0.004,0.019,0.109)$ \\
\hline S3 & $(0.005,0.045,0.315)$ & $(0.004,0.035,0.258)$ & $(0.001,0.002,0.02)$ \\
\hline I1 & $(0.004,0.019,0.109)$ & $(0,0,0)$ & $(0.001,0.007,0.059)$ \\
\hline I2 & $(0,0.002,0.016)$ & $(0,0.001,0.009)$ & $(0.002,0.01,0.05)$ \\
\hline I3 & $(0.001,0.007,0.059)$ & $(0,0.006,0.048)$ & $(0.008,0.032,0.302)$ \\
\hline Q1 & $(0.002,0.01,0.05)$ & $(0.001,0.007,0.04)$ & $(0.014,0.086,0.504)$ \\
\hline Q2 & $(0.005,0.022,0.236)$ & $(0.005,0.022,0.236)$ & $(0.01,0.067,0.412)$ \\
\hline Q3 & $(0.01,0.067,0.412)$ & & \\
\hline
\end{tabular}

Tables 14 and 15 show values for distance of each alternative from positive and negative ideal solutions. 
Table14. Distance of each alternative from the positive ideal solution.

\begin{tabular}{|c|c|c|c|c|c|c|c|c|}
\hline \multirow{2}{*}{ Alternatives } & Criteria & & & & & & & \\
\cline { 2 - 9 } & G1 & G2 & G3 & G4 & F1 & F2 & F3 & S1 \\
\hline Supplier 1 & 0.018 & 0.063 & 0.501 & 0.430 & 0 & 0 & 0 & 0 \\
\hline Supplier 2 & 0.018 & 0.063 & 0.501 & 0.430 & 0 & 0.019 & 0 & 0.006 \\
\hline Supplier 3 & 0 & 0 & 0 & 0 & 0.197 & 0.019 & 0.103 & 0 \\
\hline \multirow{2}{*}{ Alternatives } & Criteria & & & & & & & \\
\cline { 2 - 10 } & S2 & S3 & I1 & I2 & I3 & Q1 & Q2 & Q3 \\
\hline Supplier 1 & 0 & 0 & 0 & 0.002 & 0 & 0 & 0.039 & 0.054 \\
\hline Supplier 2 & 0.014 & 0.033 & 0.064 & 0.006 & 0.006 & 0.006 & 0.039 & 0.054 \\
\hline Supplier 3 & 0 & 0.033 & 0 & 0 & 0 & 0 & 0 & 0 \\
\hline
\end{tabular}

Table 15. Distance of each alternative from the negative ideal solution.

\begin{tabular}{|c|c|c|c|c|c|c|c|c|}
\hline \multirow{2}{*}{ Alternatives } & Criteria & & & & & & & \\
\cline { 2 - 10 } & G1 & G2 & G3 & G4 & F1 & F2 & F3 & S1 \\
\hline Supplier 1 & 0 & 0 & 0 & 0 & 0.197 & 0.019 & 0.103 & 0.006 \\
\hline Supplier 2 & 0 & 0 & 0 & 0 & 0.197 & 0 & 0.103 & 0 \\
\hline Supplier 3 & 0.018 & 0.063 & 0.501 & 0.430 & 0 & 0 & 0 & 0.006 \\
\hline \multirow{2}{*}{ Alternatives } & Criteria & & & & & & & \\
\cline { 2 - 10 } & S2 & S3 & I1 & I2 & I3 & Q1 & Q2 & Q3 \\
\hline Supplier 1 & 0 & 0.033 & 0.064 & 0.004 & 0.006 & 0.006 & 0 & 0 \\
\hline Supplier 2 & 0 & 0 & 0 & 0 & 0 & 0 & 0 & 0 \\
\hline Supplier 3 & 0.014 & 0 & 0.064 & 0.006 & 0.006 & 0.006 & 0.039 & 0.054 \\
\hline
\end{tabular}

Table 16 shows summation of distances of each alternative from positive and negative ideal solutions calculated using Tables 14 and 15 .

Table 16. Summation of distance of each alternative from negative and positive ideal solutions.

\begin{tabular}{|c|c|c|}
\hline Alternative & $\begin{array}{c}\text { From the positive ideal } \\
\text { solution }\left(d^{+}\right)\end{array}$ & $\begin{array}{c}\text { From the negative ideal } \\
\text { solution }\left(d^{-}\right)\end{array}$ \\
\hline Supplier 1 & 1.106 & 0.438 \\
\hline Supplier 2 & 1.258 & 0.300 \\
\hline Supplier 3 & 0.352 & 1.207 \\
\hline
\end{tabular}

The above table shows supplier 3 has the most distance from the negative ideal solution and the shortest dicance from the positive ideal solution between all of suppliers.

Table 17 shows the final results of the propose method as follows:

Results of ranking the suppliers in FTOPSIS show that the supplier3 (Sepahandaneh parsian co.) is the best supplier of livestock o poultry feed. Also, supplier2 (Khorakdame koohpayeh co.) is selected as the worst ranked supplier.

Table 17. Final results of the FTOPSIS method as follows.

\begin{tabular}{|c|c|c|}
\hline Alternative & $C_{i}$ & Rank \\
\hline Khorak sazan espadan Co & 0.284 & 2 \\
\hline Khorak dame koohpayeh Co & 0.192 & 3 \\
\hline Sepahandaneh parsian Co & 0.774 & 1 \\
\hline
\end{tabular}

\section{Conclusions}

Organizations always try to produce affordable better quality products with lower cost by standardizing and improving their internal processes in order to increase their competitive strength. This days green concept is added to Supply chain management. Recognition of green industries and production of eco-friendly products in cooperation with suppliers, is committed to environmental issues (green supplier issue) for the manufacturers. It is very important that this issue has led to the development of the concept of green supply chain management (GSCM) have been in the industry. Present research aimed to evaluated producers of feed for growing livestock and poultry in Esfahan province. Three suppliers were evaluated according to 16 criteria. The criteria were grouped into five classes of green, finance, IT, services and marketing and quality in a hierarchical structure. Then, the fuzzy weights of each criteria is computed and fuzzy TOPSIS method was used to compare suppliers according to criteria. Results showed that supplier 3 by $C_{i}$ equivalent 0.774 was the best supplier. Also, supplier 1 by $C_{i}$ equivalent 0.284 and supplier 2 by $C_{i}$ equivalent 0.192 were ranked as the second, third places, respectively; In fact, suppliers 3 with a production of environmentally friendly, green packaging, environmental training, certifications related to environmental and other criteria and implement them, is selected as the best supplier. As a result of the empirical study in livestock and poultry industry, we found that the integration of Fuzzy AHP and fuzzy TOPSIS was a practical and efficient tool for ranking candidate suppliers in terms of their overall performance with respect to multiple criteria; Because the impact of various criteria such as price, quality, environmental 
compatibility and etc. due to their factor are well understood. Using fuzzy theory for supplier selection and evaluation problem can reduce ambiguities and vagueness that are inherent in the field of supplier selection management decision problems. Finally, an experiment has been conducted to apply the proposed methodology for solving green supplier selection problems satisfactory.

For the extension of this study, fuzzy ANP and fuzzy DEMATEL method which are able to consider some inner and outer dependencies and causal relationship among criteria or alternatives can be applied. Future researches could apply the proposed methodology to develop a fuzzy group decision support system to determine policy making in green supplier selection management decision problems.

\section{Appendix}

This questionnaire has been formed to consider the views of experts then its results are used to form the hierarchical structure model

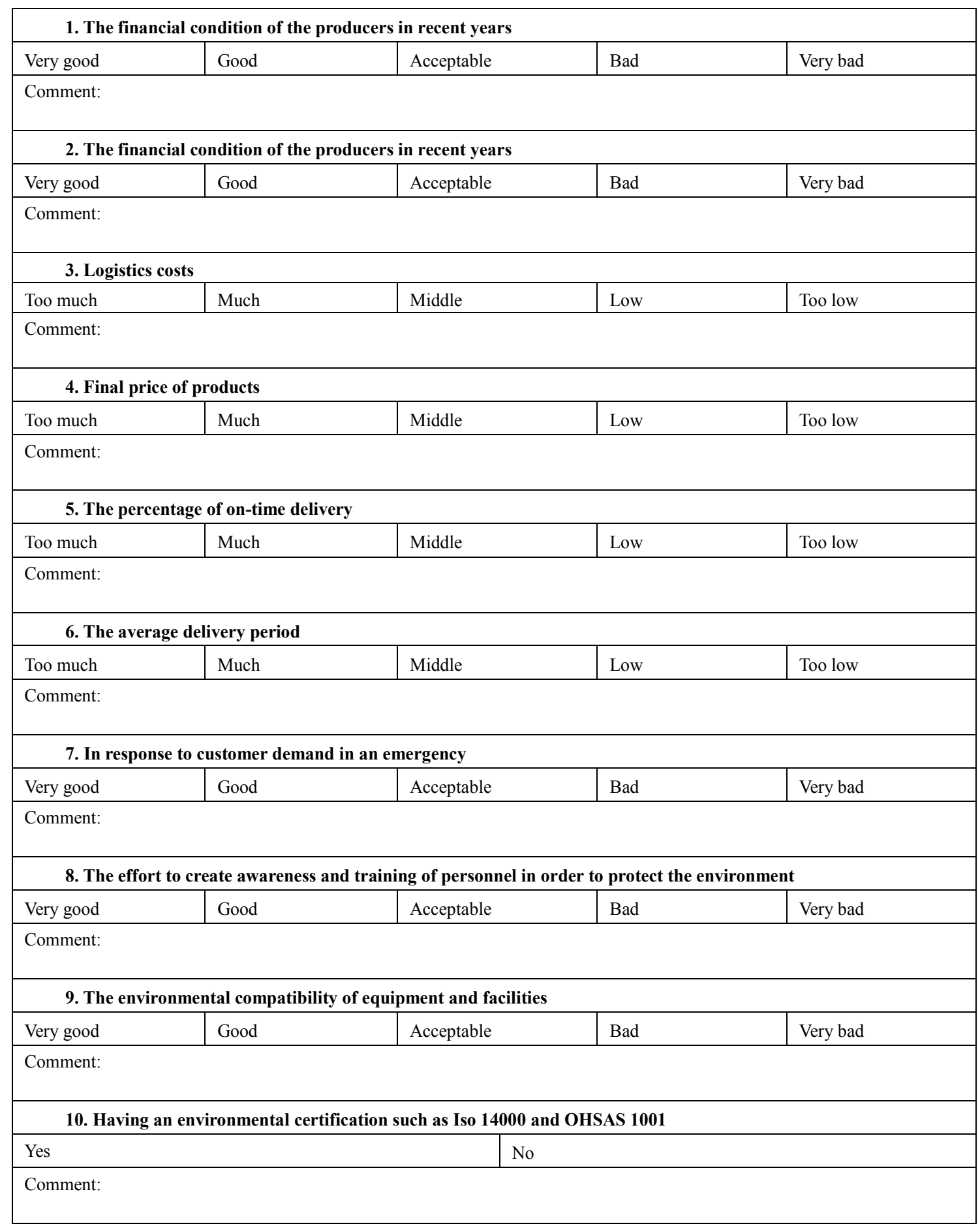




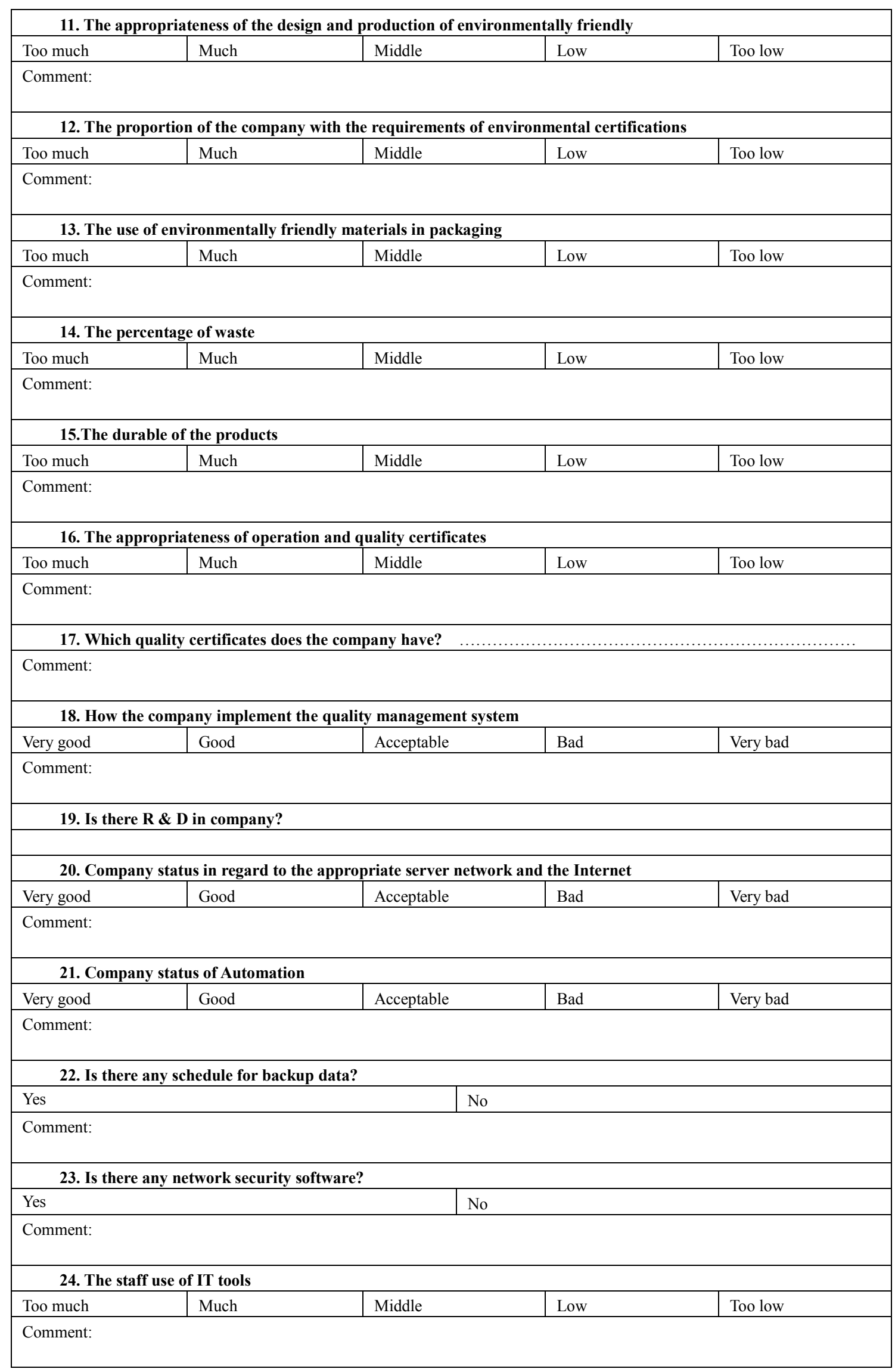




\section{REFERENCES}

[1] P.K. Humphreys, Y.K. Wong, F.T.S. Chan, Integrating environmental criteria into the supplier selection process, Journal of Materials Processing Technology 138 (2003) 156-349.

[2] Sarkis, J. (1998). Evaluating environmentally conscious business practices. European Journal of Operational Research, 107, 159-174.

[3] Hart, S. L., and Dowell, G. (2011), Invited editorial: A natural-resource-based view of the firm fifteen years after, Journal of Management, Vol.37, No.5, pp. 1464-1479.

[4] Marcus, A., \& Fremeth, A. (2009). Green management matters regardless. The Academy of Management Perspectives, 23(3), 17-26.

[5] Linton, J. D., Klassen, R., \& Jayaraman, V. (2007). Sustainable supply chains: An introduction. Journal of Operations Management, 25(6), 1075-1082.

[6] Genovese, A., Lenny Koh, S. C., Bruno, G., \& Esposito, E. (2013). Greener supplier selection: State of the art and some empirical evidence. International Journal of Production Research, 51(10), 2868-2886.

[7] Krause, D., Krause, R., Handfield, R. B., Scannell, T., Scanell V., 1998, An empirical investigation of supplier development: reactive and strategic process, Journal of Operational Management, Vol. 17, No.1, p. 39-58.

[8] Motwani, J., Youssef, M., 1999. Supplier selection in developing countries: a model development. Emerald 10 (13), 154e162.

[9] Sarkis, J., 2001. Manufacturing's role in corporate environmental sustainability: concerns for the new millennium. International Journal of Operations and Production Management 21 (5/6), 666-686.

[10] Seuring, S., Sarkis, J., Mueller, M., Rao, P., 2008. Sustainability and supply chain management - an introduction to the special issue. Journal of Cleaner Production 16 (15), 1535-1551.

[11] Zhu, Q., Sarkis, J., Lai, K.H., 2008. Confirmation of a measurement model for green supply chain management practices implementation. International Journal of Production Economics 111 (2), 261-273.

[12] Bryson, J.R., Lombardi, R., 2009. Balancing product and process sustainability against business profitability: sustainability as a competitive strategy in the property development process. Business Strategy and the Environment 18 (2), 97-107.

[13] Teunter, R.H., Flapper, S.D.P., 2011. Optimal core acquisition and remanufacturing policies under uncertain core quality fractions. European Journal of Operational Research 210 (2), 241-248.

[14] Liu, Z., Anderson, T.D., Cruz, J.M., 2012. Consumer environmental awareness and competition in two-stage supply chains. European Journal of Operational Research $218(3), 602-613$.

[15] Nagel, M.H., 2003. Managing the environmental performance of production facilities in the electronics industry: more than application of the concept of cleaner production. Journal of Cleaner Production 11 (1), 11-26.

[16] Bai, C., Sarkis, J., 2010a. Green supplier development: analytical evaluation using rough set theory. Journal of Cleaner Production 18 (12), 1200-1210.

[17] Fu, X., Zhu, Q., Sarkis, J., 2012. Evaluating green supplier development programs at a telecommunications systems provider. International Journal of Production Economics 140 (1), 357-367.

[18] Tang, C.S., Zhou, S., 2012. Research advances in environmentally and socially sustainable operations. European Journal of Operational Research 223 (3), 585594.

[19] Jabbour, A. B. L. S., \& Jabbour, C. J. C. (2009). Are supplier selection criteria going green? Case studies of companies in Brazil. Industrial Management \& Data Systems, 109(4), 477-495.

[20] Dekker, R., Bloemhof, J., Mallidis, I., 2012. Operations research for green logistics -an overview of aspects, issues, contributions and challenges. European Journal of Operational Research 219 (3), 671-679.

[21] Humphreys, P.K., Wong, Y.K., Chan, F.T.S., 2003 b. Integrating environmental criteria into the supplier selection process. Journal of Materials Processing Technology

[22] Hsu, C.W., Hu, A.H., 2009. Applying hazardous substance management to supplier selection using analytic network process. Journal of Cleaner Production 17,255e264.

[23] Ge Yan, 2009. Research on Green Suppliers' Evaluation Based on AHP \& Genetic Algorithm. International Conference on Signal Processing Systems, 615 - 619.

[24] Lee, A. H. I., Kang, H., Hsu, C., \& Hung, H. (2009). A green supplier selection model for high-tech industry. Expert Systems with Applications, 36, 7917-7927.

[25] Chen, C.C., Tseng, M.L., Lin, Y.H., Lin, Z.S., 2010. Implementation of green supply chain management in uncertainty. In: International Conference on IEEM, IEEE 7e10 Dec, pp. 260e264.

[26] Kuo, R.J., Lin, Y.J., 2011. Supplier selection using analytic network process and data envelopment analysis. International Journal of Production Research, 1e12 iFirst.

[27] Hanratty, P.J., Joseph, B., 1992. Decision-making in chemicalengineering and expert systems: application of the analytic hierarchy process to reactor selection. Computers \& Chemical Engineering 16, 849-860.

[28] Mahdipoor, H.R., 2006. Flow pattern recognition in tray columns with MADM (multiple attribute decision making) method. Computers \& Chemical Engineering 30, 11971200 .

[29] Sikdar, S.K., 2003. Sustainable development and sustainability metrics. AIChE Journal 49, 1928-1932.

[30] Sikdar, S.K., 2009. On aggregating multiple indicators into a single metric for sustainability. Clean Technologies and Environmental Policy 11, 157-161.

[31] Qian, Y., Huang, Z., Yan, Z., 2007. Integrated assessment 
of environmental and economic performance of chemical products using analytic hierarchy process approach. Chinese Journal of Chemical Engineering 15, 81-87.

[32] Othman, M.R., Repke, J.-U., Wozny, G., 2010. Incorporating negative values in AHP using rule-based scoring methodology for ranking of sustainable chemical process design options. Computer Aided Chemical Engineering 28, 1045-1050.

[33] Saaty, T.L., 1977. A scaling method for priorities in hierarchical structures. Journal of Mathematical Psychology 15, 234-281.

[34] Vaidya, O.S., Kumar, S., 2006. Analytic hierarchy process: an overview of applications. European Journal of Operational Research 169 (1), 1-29.

[35] Sipahi, S., Timor, M., 2010. The analytic hierarchy process and analytic network process: an overview of applications. Management Decisions 48 (5), 775-808.

[36] Pohekar, S.D., Ramachandran, M., 2004. Applications of multi-criterion decision-making to sustainable energy planning - a review. Renewable and Sustainable Energy Reviews 8 (4), 365-381.

[37] Arslan, O., 2009. Quantitative evaluation of precautions on chemical tanker operations. Process Safety and Environmental Protection 87 (2), 113-120.

[38] Perez-Vega, S., Peter, S., Salmeron-Ochoa, I., Nieva-De La Hidalga, A., Sharratt, P.N. Analytic hierarchy process (AHP) for the evaluation of solvents in early stages of pharmaceutical process development. Process Safety and Environmental Protection. 2011;89:261-267

[39] Zadeh, L.A., "Fuzzy Sets", Information and Control, Vol.8(3), 338-353, 1965.

[40] R.E Bellman and L.A Zadeh (1970). Decision making in a fuzzy environment, management science. Vol 17.

[41] Chen, S.-J., Hwang, C.-L., Hwang, F.-P., 1992. Fuzzy Multiple Attribute Decision-making: Methods and Applications. Springer-Verlag, Berlin.

[42] Van Laarhoven, P.J.M., Pedrycz, W., 1983. A fuzzy extension of Saaty's priority theory. Fuzzy Sets and Systems 11, 229-241.

[43] Aşkın Ozdagoglu, Guzin Ozdagoglu, "Comparison of AHP and Fuzzy AHP for the Multi criteria Decision Making Processes with Linguistic Evaluations", Istanbul Ticaret University Journal of Institute of Science, Year: 6, Vol. :11, pp. 65-85, 2007.

[44] D.Y. Chang, Applications of the extent analysis method on fuzzy-AHP, Eur. J. Oper. Res. 95 (1996) 649-655.

[45] O. Kilincci, S.A. Onal, Fuzzy-AHP approach for supplier selection in a washing machine company, Expert Syst. Appl. 38 (2011) 9656-9664.

[46] I. Ertugrul, N. Karakasoglu, Comparison of fuzzy AHP and fuzzy TOPSIS methods for facility location selection, Int. J. Adv. Manuf. Technol. 39 (2008) 783-795.

[47] Hwang, C.L., and Yoon, K., Multiple Attribute Decision Making Methods and Applications: A State of the Art Survey, Springer-Verlag, USA. (1981).
[48] A. Azadeh, S.N. Shirkouhi, K. Rezaie, A robust decision-making methodology for evaluation and selection of simulation software package, Int. J. Adv. Manuf. Technol. 47 (1-4) (2010) 381-393.

[49] C.-T. Chen, C.-T. Lin, S.-F. Huang, A fuzzy approach for supplier evaluation and selection in supply chain management, Int. J. Prod. Econ. 102 (2) (2006) 289-301.

[50] F.E. Boran, S. Genc, M. Kurt, D. Akay, A multi-criteria intuitionistic fuzzy group decision making for supplier selection with TOPSIS method, Expert Syst. Appl. 36 (8) (2009) 11363-11368.

[51] C. Kahraman, Fuzzy Multi-criteria Decision-making, Springer, 2008.

[52] A. Baykasoglu, V. Kaplanoglu, Z.D.U. Durmusoglu, C. S_ahin, Integrating fuzzy DEMATEL and fuzzy hierarchical TOPSIS methods for truck selection, Expert Syst. Appl. 40 (3) (2013) 899-907.

[53] C. Kahraman, G. Buyukozkan, N.Y. Atecs, A two phase multi-attribute decision-making approach for new product introduction, Inf. Sci. 177 (7) (2007) 1567-1582.

[54] C.-T. Chen, Extensions of the TOPSIS for group decision-making under fuzzy environment, Fuzzy Sets Syst. 114 (1) (2000) 1-9.

[55] Min, H., \& Galle, W. P. (2001). Green purchasing practices of US firms. International Journal of Operations \& Production Management, 21(9), 1222-1238.

[56] Kuo, R. J., Wang, Y. C., \& Tien, F. C. (2010). Integration of artificial neural network and MADM methods for green supplier selection. Journal of Cleaner Production,18(12), 1161-1170.

[57] Wolf, C., \& Seuring, S. (2010). Environmental impacts as buying criteria for third party logistical services. International Journal of Physical Distribution \& Logistics Management, 40(1/2), 84-102.

[58] Yeh, W. C., \& Chuang, M. C. (2011). Using multi-objective genetic algorithm for partner selection in green supply chain problems. Expert Systems with Applications, 38(4), 4244-4253.

[59] Buyukozkan, G., \& Cifci, G. (2012). A novel hybrid MCDM approach based on fuzzy DEMATEL, fuzzy ANP and fuzzy TOPSIS to evaluate green suppliers. Expert Systems with Applications, 39, 3000-3011.

[60] Shaw, K., Shankar, R., Yadav, S. S., \& Thakur, L. S. (2012). Supplier selection using fuzzy AHP and fuzzy multi-objective linear programming for developing low carbon supply chain. Expert Systems with Applications, 39(9), 8182-8192.

[61] Tseng, M. L., \& Chiu, A. S. (2013). Evaluating firm's green supply chain management in linguistic preferences. Journal of Cleaner Production, 40, 22-31.

[62] Jinus Roshandel, Seyed Sina Miri-Nargesi, Loghman Hatami-Shirkouhi(2013). Evaluating and selecting the supplier in detergent production industry using hierarchical fuzzy TOPSIS. Applied Mathematical Modelling 37 (2013) 10170-10181. 